\title{
PSEUDOHOMOZYGOUS TYPE II HYPERLIPOPROTEINEMIA
}

\author{
Keisuke Hamada, ${ }^{1}$ Tomoko TanaKa, ${ }^{1}$ Osamu Yoshil, ${ }^{1}$ Sachiyo Saito, ${ }^{1}$ \\ Kunio HAYAKAWA, ${ }^{1}$ Nobuaki KIDA, ${ }^{2}$ Sachiya OHTAKI ${ }^{2}$ \\ Yasuyuki SAKAI, ${ }^{3}$ and Hiroshi MABUCHI ${ }^{3}$ \\ ${ }^{1}$ Department of Pediatrics, Miyazaki Medical College, Miyazaki \\ 889-16, Japan \\ ${ }^{2}$ Central Laboratory of Clinical Investigation, Miyazaki \\ Medical College, Miyazaki 889-16, Japan \\ ${ }^{3}$ Second Department of Internal Medicine, School of \\ Medicine, Kanazawa University, Kanazawa 920, Japan
}

\begin{abstract}
Summary A 12-month-old boy with clinical findings suggestive of homozygous familial hypercholesterolemia, who had no secondary causes of hypercholesterolemia, and whose parents had no lipid abnormalities, was reported. No abnormalities were noted in the low density lipoprotein (LDL) receptor activities of the fibroblasts from patient, parents and sibling.

These features, combined with extreme responsiveness to available therapy, are strikingly suggestive of a new clinical hypercholesterolemic syndrome with manifestations resembling homozygous familial hypercholesterolemia.
\end{abstract}

\section{INTRODUCTION}

Familial hypercholesterolemia (familial type II hyperlipoproteinemia) is characterized by significantly elevated serum concentrations of cholesterol and LDL. It appears to be transmitted by a Mendelian dominant mode of inheritance and has high penetrance in early childhood (Fredrickson et al., 1978). The gene is expressed in both homozygotes and heterozygotes. There is considerable difference in the occurrence of clinical features and the serum lipid and lipoprotein levels between homozygotes and heterozygotes (Levy and Rifkind, 1973; Fredrickson et al., 1978).

The present paper is concerned with a peculiar case without potential secondary causes of hypercholesterolemia, which had clinical features and serum lipid and lipoprotein patterns suggestive of the homozygous type of familial hypercholesterolemia, although no abnormalities were found in the LDL receptor activities of the fibroblasts.

Received February 26, 1982 


\section{CASE REPORT}

A 12-month-old boy was admitted for evaluation of orange-yellow streaks over the dorsal surfaces of wrists and Achilles tendons. He was the second child of two from the same parents of non-consanguineous marriage (Fig. 1). He was born at term weighing $3,700 \mathrm{~g}$ after a normal delivery. Developmental milestones were normal.

At 11 months of age, he was first noted by his parents to have flat orangeyellow streaks over the dorsal surfaces of wrists and Achilles tendons. At 12 months of age, he was taken to dermatologists in our hospital, and then refered to our clinic for presumed diagnosis of hypercholesterolemic xanthomas.

On admission he was bright, well-developed boy without any complaints. Physical examination was completely normal except for xanthomas. Slightly elevated orange-yellow streaks lying superficially in the skin over the dorsal surfaces of wrists and Achilles tendons were easily seen. Serum lipid and lipoprotein determinations on admission revealed: total cholesterol $584 \mathrm{mg} / \mathrm{dl}$, triglyceride $94 \mathrm{mg} /$ $\mathrm{dl}$, phospholipid $345 \mathrm{mg} / \mathrm{dl}$, $\beta$-lipoprotein $1,577 \mathrm{mg} / \mathrm{dl}$, LDL $1,341 \mathrm{mg} / \mathrm{dl}$, LDL cholesterol $541 \mathrm{mg} / \mathrm{dl}$, and high density lipoprotein (HDL) cholesterol $24 \mathrm{mg} / \mathrm{dl}$. Serum lipoprotein electrophoresis in agarose gel showed a IIa pattern in the WHO classification (WHO memorundom, 1972). The following laboratory blood determinations were within normal limits: glucose, glucose tolerance test, blood nitrogen urea, electrolytes, GOT, GPT, alkaline phosphatase, bilirubin, protein electrophoresis, TSH, $\mathrm{T}_{3}, \mathrm{~T}_{4}$. Urinalysis, roentogenograms of the chest, and ECG were also within normal limits.

A diagnosis of familial hypercholesterolemia in Japanese requires either (1) hypercholesterolemia greater than $250 \mathrm{mg} / \mathrm{dl}$ with tendon xanthomas or Achilles tendons of increased thickness, or (2) hypercholesterolemia greater than $250 \mathrm{mg} / \mathrm{dl}$

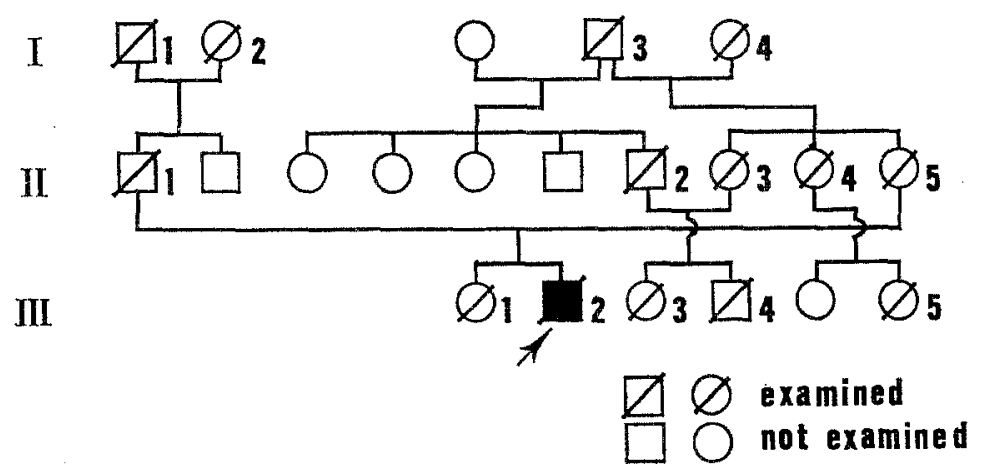

Fig. 1. Pedigree of patient's family. The proband is III-2. Serum total cholesterol, low density lipoprotein cholesterol, and triglycerides levels of the family members are given in Table 1. 
in first degree relatives with familial hypercholesterolemia (Mabuchi et al., 1977). Neither the lipid abnormalities compatible with these diagnostic criteria nor episodes of xanthomas and premature ischemic heart disease were noted in this patient's parents and relatives (Fig. 1, Table 1).

At 39 months of age, determination of surface-bound, intracellular, and degraded ${ }^{125} \mathrm{I}-\mathrm{LDL}$ in fibroblast monolayers was carried out by the methods of Goldstein et al. $(1974,1977)$; Cell monolayers were grown in dishes containing $3 \mathrm{ml}$ of growth medium. On the 5 th or 6 th day, the monolayers received $3 \mathrm{ml}$ of medium containing 5\% lipoprotein-deficient serum (LPDS). After incubation for $48 \mathrm{hr}$, the cells received $2 \mathrm{ml}$ of fresh medium containing $5 \%$ LPDS and $10 \mu \mathrm{g}$ protein $/ \mathrm{ml}$ of ${ }^{125} \mathrm{I}-\mathrm{LDL}(33-100 \mathrm{cpm} / \mathrm{ng})$. After incubation for $6 \mathrm{hr}$, surface-bound, internalized, and degraded ${ }^{125}$ I-LDL were determined (Haba et al., 1981). The results of these determinations showed that fibroblasts from patient, parents and sibling had normal LDL receptor activity (Table 2).

Treatment was started with the combined use of diet and a small dose of cholestylamine. After 10 days of this treatment, serum total cholesterol, LDL and LDL cholesterol had decreased to $131 \mathrm{mg} / \mathrm{dl}, 211 \mathrm{mg} / \mathrm{dl}$ and $76 \mathrm{mg} / \mathrm{dl}$, respectively. Cholestylamine was discontinued after 8 weeks. Serum total cholesterol remained between $115 \mathrm{mg} / \mathrm{dl}$ and $280 \mathrm{mg} / \mathrm{dl}$ over the subsequent 28 months on dietary management alone. The xanthomas regressed rapidly and disappeared in 9 months after the start of treatment (Fig. 2).

Table 1. Serum total cholesterol, low density lipoprotein cholesterol, and triglycerides levels in family.

\begin{tabular}{ccccc}
\hline $\begin{array}{c}\text { Position of } \\
\text { subjects in } \\
\text { pedigree }\end{array}$ & Age \& sex & \multicolumn{2}{c}{ Cholesterol (mg/dl) } & \multirow{2}{*}{$\begin{array}{c}\text { Triglycerides } \\
\text { (mg/d) }\end{array}$} \\
\cline { 3 - 4 } & Total & LDL & 55 \\
I-1 & 75, male & 93 & 52 & 85 \\
I-2 & 65, female & 238 & 178 & 91 \\
I-3 & 75, male & 170 & 107 & 195 \\
I-4 & 60, female & 235 & 145 & 142 \\
II-1 & 29, male & 212 & 152 & 160 \\
II-2 & 40, male & 180 & 109 & 123 \\
II-3 & 37, female & 159 & 77 & 65 \\
II-4 & 30, female & 193 & 89 & 101 \\
II-5 & 29, female & 186 & 126 & 80 \\
III-1 & 3, female & 180 & 123 & 94 \\
III-2 & 1, male & 584 & 541 & 124 \\
III-3 & 16, female & 186 & 117 & 114 \\
III-4 & 13, male & 180 & 100 & 52 \\
III-5 & 5, female & 103 & 59 & \\
\hline
\end{tabular}

Vol. 27, No. 3, 1982 
Table 2. High-affinity binding, internalization, and degradation of ${ }^{125} \mathrm{I}-\mathrm{LDL}$ in fibroblasts.

\begin{tabular}{|c|c|c|c|}
\hline Cell strain & $\begin{array}{l}\text { Receptor-bound } \\
{ }^{225} \text { I-LDL, ng/mg }\end{array}$ & $\begin{array}{c}\text { Internalized } \\
{ }^{12 \sigma}[-\mathrm{LDL}, \mathrm{ng} / \mathrm{mg}\end{array}$ & $\begin{array}{c}\text { Degraded } \\
{ }^{12 \pi}[-\mathrm{LDL}, \mathrm{ng} / \mathrm{mg}\end{array}$ \\
\hline Patient (III-2) & 50 & 188 & 719 \\
\hline Father (II-I) & 71 & 224 & 1,607 \\
\hline Mother (II-5) & 106 & 328 & 2,969 \\
\hline Sister (III-1) & 30 & 238 & 839 \\
\hline Normal subjects $(n=4)$ & $44 \pm 3^{*}$ & $386 \pm 32^{*}$ & $1,335 \pm 214^{*}$ \\
\hline Heterozygotes $(n=5)$ & $24 \pm 3$ & $147 \pm 19$ & $614 \pm 65$ \\
\hline \multicolumn{4}{|l|}{ Homozygotes } \\
\hline Receptor-defective $(n=3)$ & $6 \pm 2$ & $29 \pm 8$ & $90 \pm 32$ \\
\hline Receptor-negative $(n=4)$ & $0.4 \pm 0.2$ & $14 \pm 6$ & $7 \pm 5$ \\
\hline
\end{tabular}

* Mean \pm SEM

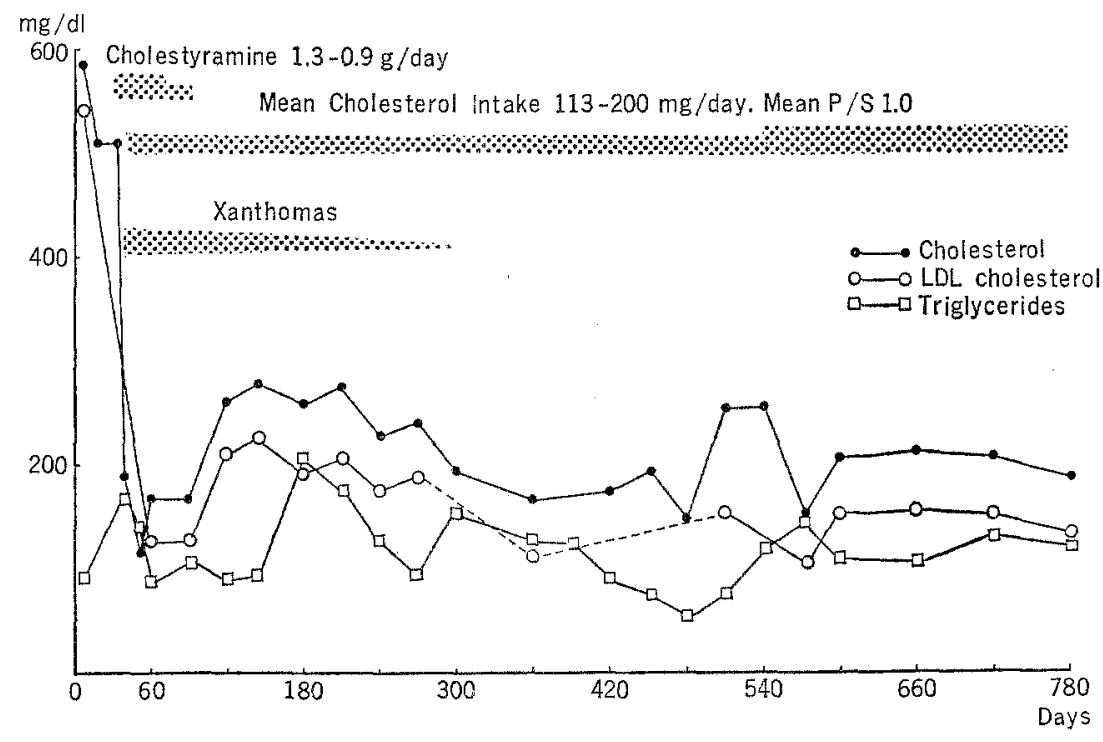

Fig. 2. Clinical course of patient. $\mathrm{P} / \mathrm{S}$, polyunsaturated to saturated fatty acid ratio.

\section{DISCUSSION}

Analysis of families known to be affected with familial hypercholesterolemia, using either plasma total cholesterol or LDL cholesterol level as a genetic marker, has revealed that the gene is highly penetrant at all ages, with a calculated penetrance value ranging from $90 \%$ to $100 \%$ (Fredrickson et al., 1978). It is now also demonstrated that mutant cells from homozygotes have a deficiency in the LDL receptor on the cell surface, and that at least three different mutations (i.e., receptor-negative, 
receptor-defective, and internalization defect) can cause homozygous familial hypercholesterolemia (Goldstein et al., 1977; 1979).

The mean and standard deviation (SD) of plasma total cholesterol and LDL cholesterol levels in American heterozygotes aged one to 19 years were $299 \pm 63$ $\mathrm{mg} / \mathrm{dl}$ and $241 \pm 60 \mathrm{mg} / \mathrm{dl}$, respectively, and in homozygotes, $678 \pm 170 \mathrm{mg} / \mathrm{dl}$ and $625 \pm 160 \mathrm{mg} / \mathrm{dl}$, respectively (Kwiterowich et al., 1974). In Japanese heterozygotes aged 2 to 52 years, the mean and SD of serum total cholesterol levels were $342 \pm 79$ $\mathrm{mg} / \mathrm{dl}$ (range, 241 to $571 \mathrm{mg} / \mathrm{dl}$ ), and in homozygotes, $713 \pm 142 \mathrm{mg} / \mathrm{dl}$ (range, 508 to $1,108 \mathrm{mg} / \mathrm{d} 1$ ) (Mabuchi et al., 1978). These results suggest that the mean plasma or serum total cholesterol levels for homozygotes with familial hypercholesterolemia is approximately double that of heterozygotes, and nearly quadruple that of normal subjects.

There is considerable difference in the occurrence of xanthomas between homozygotes and heterozygotes. In homozygotes, xanthomas are noted at birth, or during the period of the first few years of life in almost all cases, but in heterozygotes there is a long lag before xanthomas appear (West and Lloyd, 1979).

The combined use of diet and cholestylamine for a long term (two- to threeyears) effects a significant reduction in serum total cholesterol levels in $60 \%$ of heterozygous children (Glueck et al., 1977). In most cases in homozygotes, however, serum total cholesterol has not been lowered beyond about $500 \mathrm{mg} / \mathrm{dl}$ on the same combined therapy (West and Lloyd, 1979).

The main findings in the present case, considering the characteristics of familial hypercholesterolemia as formerly mentioned, are as follows; (1) the occurrence of xanthomas, and serum lipid and lipoprotein patterns were compatible with those of homozygous familial hypercholesterolemia, (2) no lipid abnormalities were found in parents and relatives, (3) potential secondary causes of hypercholesterolemia were carefully excluded, (4) the combined use of diet and a small dose of cholestylamine produced an extreme reduction of serum total cholesterol, LDL, and LDL cholesterol levels, causing the xanthomas to regress rapidly and disappear, and (5) fibroblasts from patient, parents and sibling had normal LDL receptor activity.

Two original cases with the same characteristics as the present case were reported by Morganroth et al. (1974), and it was demonstrated by Goldstein and Brown (1979) that fibroblasts from these patients had normal LDL receptor activity. The additional case with an older sister who had the biochemical features of the heterozygous state was reported by Mishkel (1976), but LDL receptor activity of the cultured fibroblasts was not examined. This evidence for familial occurrence of this disorder suggests that it is not due to an autosomal dominant gene, but due to an autosomal recessive gene. However, it is necessary to accumulate further cases before any definite conclusion can be drawn about the hereditary nature of this disorder.

A study of the present case together with two cases in the literature (Morganroth et al., 1974; Goldstein and Brown, 1979) also suggests that the phenomena 
associated with LDL receptor mutations are not accommodated into the pathogenesis of this disorder. Accordingly, at this time we agree with previous authors (Morganroth et al., 1974; Mishkel, 1976) that these cases appear to represent a new clinical hypercholesterolemic syndrome with manifestations resembling homozygous familial hypercholesterolemia.

\section{REFERENCES}

Fredrickson, D.S., Goldstein, J.L., and Brown, M.S. 1978. The familial hyperlipoproteinemia. In The Metabolic Basis of Inherited Disease, Stunbery, J.B., ed., McGraw-Hill Book Co., New York pp. 617-633,

Glueck, C.J., Tsang, M.D., Fallot, R.W., and Mellies, M. 1977. Therapy of familial hypercholesterolemia in childhood: Diet and cholestylamine resin for 24 to 36 months. Pediatrics 59: $433-441$.

Goldstein, J.L., and Brown, M.S. 1974. Binding and degradation of low density lipoproteins by cultured human fibroblasts: Comparison of cell from a normal subject and a patient with homozygous familial hypercholesterolemia. J. Biol. Chem. 249: 5153-5162.

Goldstein, J.L., Brown, M.S., and Stone, N.J. 1977. Genetics of the LDL receptor: evidence that the mutations affecting binding and internalization are allelic. Cell 12: 629-641.

Goldstein, J.L., and Brown, M.S. 1979. The LDL receptor locus and the genetics of familial hypercholesterolemia. Ann. Rev. Genet. 13: 259-289.

Haba, T., Mabuchi, H., Yoshimura, A., Watanabe, A., Wakasugi, T., Tatami, R., Ueda, K., Kametani, T., Koizumi, J., Miyamoto, S., Takeda, R., and Takeshita, H. 1981. Effects of ML-236B (Compactin) on sterol synthesis and low density lipoprotein receptor avtivities in fibroblasts of patients with homozygous familial hypercholesterolemia. J. Clin. Invest. 67: $1532-1540$.

Kwiterowich, P.O., Fredrickson, D.S., and Levy, R.I. 1974. Familial hypercholesterolemia (one form of familial type II hyperlipoproteinernia). A study of its biochenical, genetic, and clinical presentation in childhood. J. Clin. Invest. 53: 1237-1249.

Levy, R.I., and Rifkind, B.M. 1973. Diagnosis and management of hyperlipoproteinemia in infants and children. Am. J. Cardiol. 31: 547-556.

Mabuchi, H., Haba, T., Ueda, K., Ueda, R., Tatami, R., Itoh, S., Kametani, T., Koizumi, J., Miyamoto, S., Ohta, M., Takeda, R., Takegoshi, T., and Takeshita, H. 1977. Serum lipids and coronary heart disease in heterozygous familial hypercholesterolemia in the Hokuriku district of Japan. Atherosclerosis 28: 417-423.

Mabuchi, H., Tatami, R., Haba, T., Ueda, K., Ueda, R., Kametani, T., Itoh, S., Koizumi, T., Ohta, M., Miyamoto, S., Takeda, R., and Takeshita, H. 1978. Homozygous familial hypercholesterolemia in Japan. Am. J. Med. 65: 290-297.

Mishkel, M.A. 1976. Pseudohomozygous and pseudoheterozygous type II hyperlipoproteinemia. Am. J. Dis. Child. 130: 991-993.

Morganroth, J., Levy, R.I., McMahon, A.I., and Gotto, A.M., Jr. 1974. Pseudohomozygous type II hyperlipoproteinemia. J. Pediatr. 85: 639-643.

West, R.J., and Lloyd, J.K. 1979. Hypercholesterolemia in childhood. In Advances in Pediatrics, Barness, L.A., ed., Year Book Med. Publ. Inc., Chicago pp. 1-34.

WHO memorundom. 1972. Classification of hyperlipidemias and hyperlipoproteinemia. Circulation 45: 501-508. 